\title{
REVIEW
}

\section{Mechanisms behind the non-thyroidal illness syndrome: an update}

\author{
Maria H Warner and Geoffrey J Beckett \\ Clinical Biochemistry, University of Edinburgh, The Royal Infirmary of Edinburgh, 51 Little France Crescent, Edinburgh EH16 4SA, UK \\ (Correspondence should be addressed to G J Beckett; Email: g.j.beckett@ed.ac.uk)
}

\begin{abstract}
The mechanisms behind the changes in serum triiodothyronine $\left(\mathrm{T}_{3}\right)$, thyroxine $\left(\mathrm{T}_{4}\right)$ and TSH that occur in the nonthyroidal illness syndrome (NTIS) are becoming clearer. Induction of a central hypothyroidism occurs due to a diminution in hypothalamic thyrotropin-releasing hormone. This can be signalled by a decrease in leptin caused by malnutrition and possibly a localised increase in hypothalamic $\mathrm{T}_{3}$ catalyzed by altered expression of hypothalamic iodothyronine deiodinases D2 and D3. Data from D1 and D2 knockout mice suggest that these enzymes may have little contribution to the low serum $\mathrm{T}_{3}$ found in acute illness. The decline in serum $\mathrm{T}_{3}$ and $\mathrm{T}_{4}$ in models of acute illness precedes the fall in hepatic D1, suggesting that much of the initial fall in these hormones may be attributable to an acute phase response giving rise to a
\end{abstract}

reduction in the thyroid hormone binding capacity of plasma. When measured by reliable methods, changes in serum free $T_{4}$ and free $T_{3}$ are modest in comparison to the fall seen in total thyroid hormone. Thyroid hormone transporter expression is up-regulated in many models of the NTIS, thus if diminished tissue uptake of hormone occurs in vivo, it is likely to be the result of impaired transporter function caused by diminished intracellular ATP or plasma inhibitors of transporter action. In man, chronic illness leads to an upregulation of thyroid hormone receptor (THR) expression at least in liver and renal failure. In contrast, human and animal models of sepsis and trauma indicate that expression of THRs and their coactivators are decreased in acute illness.

Journal of Endocrinology (2010) 205, 1-13

\section{Introduction}

Illness may induce profound changes in a number of neuroendocrine systems. The activation of the pituitaryadrenal axis is common, and plasma cortisol concentrations rise rapidly as a result of the acute stress response. The extent of this rise is related to the severity of the illness and is critical for survival (Vermes \& Beishuizen 2001). Changes within the hypothalamic-pituitary-thyroid (HPT) axis also occur in illness and are typically associated with low levels of total triiodothyronine $\left(\mathrm{T}_{3}\right)$, and this has given rise to the term 'low $\mathrm{T}_{3}$ syndrome'. Sick patients with low serum $\mathrm{T}_{3}$ are often regarded as being clinically euthyroid, and as a consequence, the alternative term 'Euthyroid sick syndrome' was widely used in the past. 'Non-thyroidal illness syndrome (NTIS)' is now more commonly used to describe the typical changes in thyroid-related hormone concentrations that can arise in the serum following any acute or chronic illness that is not caused by an intrinsic abnormality in thyroid function. It has been much debated whether these changes in the HPT axis during illness are representative of an associated pathology requiring thyroid hormone replacement therapy or are indeed an adaptive response to 'stress' to decrease metabolic rate, which in turn may be beneficial to the sick patient.
A wide range of mechanisms give rise to the hormonal changes seen in the NTIS; these include modifications to the hypothalamic-pituitary axis, altered binding of thyroid hormone to circulating binding proteins, modified entry of thyroid hormone into tissue, changes in thyroid hormone metabolism due to modified expression of the intracellular iodothyronine deiodinases and changes in thyroid hormone receptor (THR) expression or function. In this review, the current state of knowledge regarding these processes will be described together with the current consensus view on the need for clinical intervention with thyroid hormone replacement in such sick patients.

\section{Typical changes in thyroid function tests in illness}

Mild thyroid disease is very common and may present with only vague non-specific symptoms, particularly in the elderly. Such patients can be readily identified by using 'thyroid function tests', measurement of serum thyrotrophin (TSH), thyroxine $\left(T_{4}\right)$ and $T_{3}$. Thyroid function testing becomes problematic when the tests are performed in patients who have any significant co-existing illness (organic or 


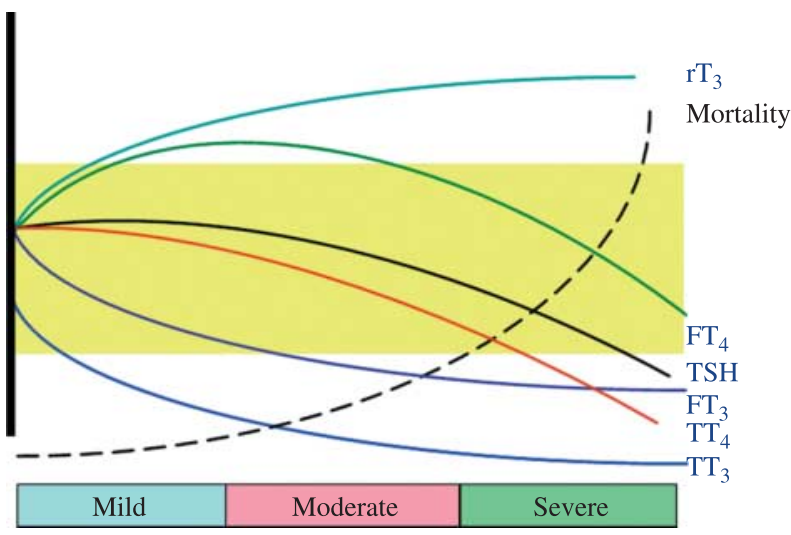

Figure 1 Schema showing the general changes that occur in serum thyroid-related hormones following illness of varying severity. The yellow area represents the reference range. The changes for free $T_{4}$ and free $T_{3}$ represent those found using either ultrafiltration or equilibrium dialysis of serum with low sample dilution. Publications that use methods for free hormone measurement that are unreliable in situations of low serum hormone binding capacity tend to follow the same profile as for total $T_{3}$ and total $T_{4}$ (see text for full explanation).

psychiatric), since the illness per se may give rise to changes in thyroid function tests that mimic a thyroid disorder (Fig. 1).

A decrease in $T_{3}$ is the most common finding in 'euthyroid' sick patients, occurring in even the mildest forms of non-thyroidal illness (NTI). Patients with moderate to severe illness may also show abnormalities in TSH and $\mathrm{T}_{4}$. Whilst serum TSH is regarded clinically as being the most sensitive and specific thyroid function test, in the acute hospital setting, as many as $3 \%$ of patients may exhibit TSH concentrations that are $<0.1 \mathrm{mU} / 1$ (typical TSH reference range $0 \cdot 3-4 \cdot 0 \mathrm{mU} / \mathrm{l})$, and in around $75 \%$ of these patients, the low TSH can be attributed to the NTIS or the use of glucocorticoid or dopamine medication causing TSH suppression (Spencer et al. 1987). During recovery from illness, TSH may increase transiently above the reference range (Spencer et al. 1987). Similarly, a high, normal or low $\mathrm{T}_{4}$ may also occur in sick patients. In the intensive care unit, the prevalence of abnormal thyroid function tests is extremely high with more than $70 \%$ of patients showing low total $\mathrm{T}_{3}$ and around $50 \%$ have low total $\mathrm{T}_{4}$ (Ray et al. 2002).

The abnormalities in thyroid function tests are not limited to organic illness but also manifest themselves in acute psychiatric admissions (Hein \& Jackson 1990, Arem \& Cusi 1997, Premachandra et al. 2006, Sabeen et al. 2009). In such patients, a raised $\mathrm{T}_{4}$ is frequently found with either a normal or high TSH, suggesting central activation of the HPT axis. In most instances, the thyroid function tests normalise within 2 weeks of admission (Hein \& Jackson 1990). Suppressed TSH levels, usually associated with a normal free $\mathrm{T}_{4}\left(\mathrm{FT}_{4}\right)$, have also been described in such psychiatric patients.

With regard to serum $\mathrm{FT}_{4}$ and free $\mathrm{T}_{3}\left(\mathrm{FT}_{3}\right)$, the picture is complicated further by the fact that the changes in free hormone concentration observed in illness vary according to the analytical method (Beckett 2006). Reference methods often show an increase in $\mathrm{FT}_{4}$ with illness of a moderate severity, whilst less robust assays that are commonly used for routine diagnostic purposes often show subnormal results in the same samples (Beckett et al. 1991). Similarly, the prevalence of a low $\mathrm{FT}_{3}$ in illness is dependent on the methodology (Faber et al. 1987, Faber \& SiersbaekNielsen 1996, Beckett 2006). These analytical problems are discussed later.

\section{Changes to the hypothalamic-pituitary axis in organic illness}

In illness and central hypothyroidism, serum TSH is often normal but may be suppressed despite the fact that circulating $\mathrm{T}_{3}$ may be low. Both central hypothyroidism and critical illness result in a similar decline in the usual nocturnal surge and pulse amplitude of TSH, and in addition, TSH with impaired biological action may be produced in both conditions (Adriaanse et al. 1993, Bartalena et al. 1993, Fliers et al. 1997, 2006).

Using sensitive TSH assays, it has become apparent that whilst almost all hyperthyroid patients have TSH values $<0 \cdot 01 \mathrm{mU} / \mathrm{l}$, most patients with low TSH due to the NTIS have serum TSH concentrations, which are $>0.01 \mathrm{mU} / 1$ (Spencer 1988). This is despite a low serum $\mathrm{T}_{3}$ and a reported $50 \%$ reduction in overall hypothalamic and pituitary $\mathrm{T}_{3}$ levels in illness, which under normal circumstances should lead to an increase in thyrotropin-releasing hormone (TRH) and TSH secretion.

It seems that the low TSH associated with critical illness (or failure of TSH to rise in the presence of a low $\mathrm{T}_{3}$ and $\mathrm{T}_{4}$ ) arises from a central hypothyroidism caused by alterations in the set point of the HPT axis. Specific groups of TRH neurons situated in the paraventricular nucleus (PVN) of the hypothalamus are required to promote TSH synthesis in the pituitary and regulate thyroid hormone synthesis, and such neurons appear to be the focus of the set point in the HPT axis (Fliers et al. 2001, 2006). A loss of TRH gene expression occurs in PVN samples taken at post-mortem from patients with prolonged illness who died with serum biochemistry typical of the NTIS (Fliers et al. 1997). Furthermore, administering TRH and GH secretogogues to patients with prolonged critical illness at least partially restores serum $T_{3}$, TSH and $\mathrm{T}_{4}$ (van der Heyden et al. 1986, Van den Berghe et al. 1998, 1999, 2002).

It is likely that there may be multiple causes for the loss of TRH in hypothalamic neurons in the NTIS including prolonged diminished calorie intake and release of inflammatory cytokines. In some sick patients, an increase in serum $\mathrm{FT}_{4}$ occurs (when measured by a reference method), which potentially may feedback on the hypothalamus/pituitary to moderate TRH/TSH release (Beckett et al. 1991). 
Mechanisms regulating hypothalamic TRH production in illness and fasting

A number of factors mediate the effects of physiological stimuli on the TRH neurons of the PVN (Fliers et al. 2001, 2006, Lechan \& Fekete 2004, Fekete \& Lechan 2007, Lechan 2008, Chiamolera \& Wondisford 2009, Mebis et al. $2009 b$ and references therein).

\section{Fasting}

Fasting leads to a diminution in steady state $\mathrm{T}_{3}$ levels and lowers the set point of the HPT axis. Decreased TRH in the PVN occurs in fasting and is thought to be brought about through decreases in leptin. This action of leptin appears to involve two principal classes of neuroendocrine cells in the arcuate nucleus (Fig. 2). The neurons of the PVN that secrete TRH are innervated by neurons from the arcuate nucleus that contain $\boldsymbol{\alpha}$-melanocyte-stimulating hormone $(\boldsymbol{\alpha}$-MSH or MC1R), neuropeptide Y (NPY), agouti-related protein (AGRP) and the inhibitory neurotransmitter GABA. Both NPY and AGRP stimulate food intake. Recent work indicates that hypothalamic $\mathrm{T}_{3}$ production, catalyzed by $\mathrm{D} 2$, triggers the production of mitochondrial uncoupling protein 2 , which is critical for the appropriate activation of NPY/AgRP neurons in the arcuate nucleus during fasting (Coppola et al. 2007).
Both NPY and AGRP inhibit TRH gene expression, an action accentuated by gherelin and prevented by leptin. In contrast, $\boldsymbol{\alpha}-\mathrm{MSH}$ stimulates TRH gene expression in the cells of the PVN, and this effect is enhanced by leptin (Fig. 2). It is presumed that the inhibitory effect of AGRP on TRH gene expression is due to it antagonising the effects of $\alpha-\mathrm{MSH}$, whereas the inhibitory effect of NPY occurs by reducing cAMP. During fasting, when leptin decreases, the inhibition of $\alpha-\mathrm{MSH}$ production and the concurrent increase in AGRP and NPY production reduce CREB phosphorylation in TRH neurons, thereby reducing the set point for feedback inhibition of the TRH gene by thyroid hormone. Animals deprived of food show a decline in $\mathrm{T}_{3}$ and TRH in the PVN similar to the changes found in NTIS, and such changes can be reversed by giving leptin or introducing lesions into the hypothalamic arcuate nucleus. Although the above observations relating to fasting may in part explain the changes in PVN TRH found in illness, other factors that are disease specific may also operate. For example, in infection, $\alpha-M S H$ gene expression is increased rather than decreased, which in turn should promote TRH production (Sergeyev et al. 2001). However, given that malnutrition is a component of many acute and chronic illnesses, it is impossible to separate the effects of starvation from systemic illness in an individual patient.
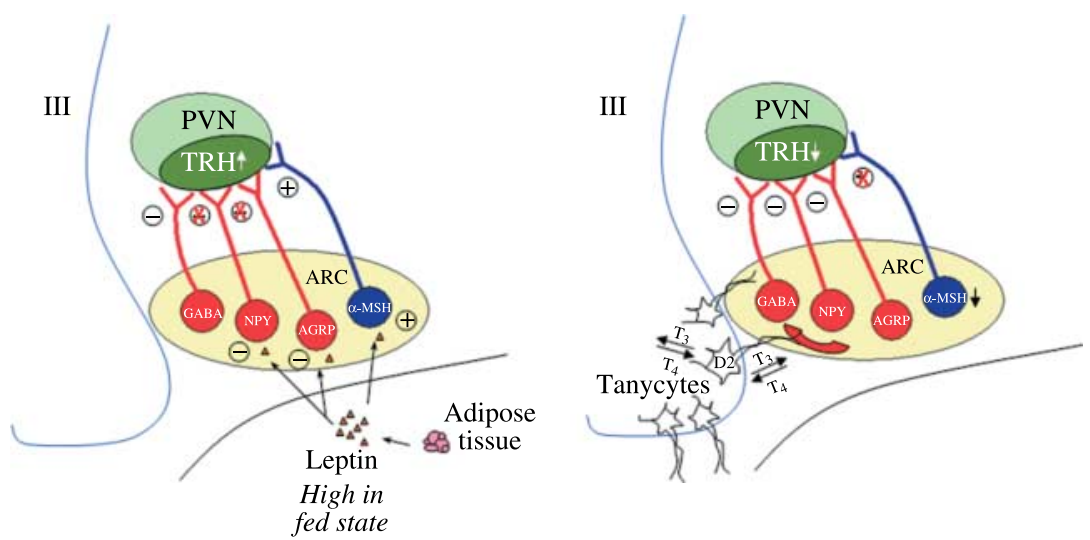

Figure 2 Proposed mechanisms behind the central hypothyroidism (low hypothalamic TRH) induced by the NTIS and fasting. (Left panel) The neurons of the paraventricular nucleus (PVN) that secrete TRH are innervated by neurons from the arcuate nucleus (ARC) that contain melanocyte-stimulating hormone $(\alpha-M S H)$, neuropeptide $Y(N P Y)$, agouti-related protein (AGRP), and the inhibitory neurotransmitter GABA. Both NPY and AGRP inhibit TRH gene expression, an action prevented by leptin. During fasting, when leptin decreases, the inhibitory actions of NPY of AGRP can prevail leading to diminished TRH. The expression of TRH in the PVN is stimulated by MSH, and this effect is enhanced by leptin. Thus, in fasting (low leptin), the stimulatory action of MSH on TRH expression in the PVN is diminished. (Right panel) $\mathrm{T}_{3}$ produced by iodothyroinine deiodinase D2 in tanycytes has important feedback inhibitory actions on TRH production in the PVN. During sepsis and trauma, there is an increase in tanycyte D2, which is postulated to lead to an increased generation of $T_{3}$ from $\mathrm{T}_{4}$. Tanycyte processes may extract $\mathrm{T}_{4}$ from portal capillaries, blood vessels in the arcuate nucleus or the CSF (in the third ventricle). The $T_{3}$ can then be released back into the CSF or the blood stream. TRH neurons may take up $\mathrm{T}_{3}$ via diffusion from the CSF, by axonal terminals of the TRH neurons present in the median eminence, or the release of $\mathrm{T}_{3}$ into the arcuate nucleus may influence the activity of arcuate neurons that project into the PVN (Lechan \& Fekete 2005). 


\section{Sepsis and trauma}

$\mathrm{T}_{3}$ has an important feedback inhibitory action on TRH production in the PVN but TRH neurons lack the ability to produce $T_{3}$ from $T_{4}$ and as such appear unable to directly sense circulating $T_{4}$. The tanycyte is a unique glial cell type that lines the floor of the third ventrical having processes that extend deep into the hypothalamus. These cells in the mediobasal hypothalamus may be an important source of $T_{3}$ to provide localised feedback regulation on the TRH neuron situated in the PVN (Fliers et al. 2001, 2006, Lechan 2008). During sepsis and trauma, there is an increase in tanycyte D2, which is postulated to lead to an increased generation of $T_{3}$ from $T_{4}$. Tanycyte processes may extract $T_{4}$ from portal capillaries, blood vessels in the arcuate nucleus or the CSF (in the third ventricle). The $\mathrm{T}_{3}$ can then be released back into the CSF or the blood stream. TRH neurons may take up $\mathrm{T}_{3}$ via diffusion from the CSF, by axonal terminals of the TRH neurons present in the median eminence, or the release of $T_{3}$ into the arcuate nucleus may influence the activity of arcuate neurons that project into the PVN (Fig. 3; Lechan \& Fekete 2005).

Recent studies in rodents highlight the potential importance of the tanycyte in sepsis for eliciting a downregulation of TRH production and modifying the set point of the HPT axis to produce central hypothyroidism. Administration of bacterial lipopolysaccraride (LPS) to rats produces a fourfold increase in D2 in the hypothalamus (Fekete et al. 2004, 2005), and a similar effect is seen in LPS-treated mice or mice subjected to chronic inflammation induced by turpentine (Boelen et al. 2006). LPS treatment produces little effect on D2 expression in the anterior pituitary of these animals suggesting a cell-specific effect on hypothalamic D2 in sepsis, which is independent of a decrease in circulating $T_{3}$. Inflammation induced by turpentine also decreases the expression of D3 in the hypothalamus (D3 metabolises $\mathrm{T}_{3}$ to inactive $T_{2}$ ) accompanied by a lowering of hypothalamic TRH (Boelen et al. 2006). Thus, infection may initiate D2-mediated increased conversion of $\mathrm{T}_{4}$ to $\mathrm{T}_{3}$ and diminished D3-mediated catabolism of $\mathrm{T}_{3}$ (Fig. 3) leading to a local tissue hyperthyroidism, which in turn exerts a negative feedback control on TRH synthesis in hypophysiotropic neurons (Fig. 2). It is not yet known whether these or similar mechanisms operate in humans, but in a rabbit model

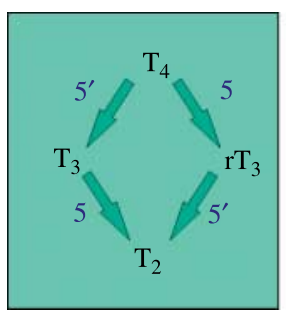

D1

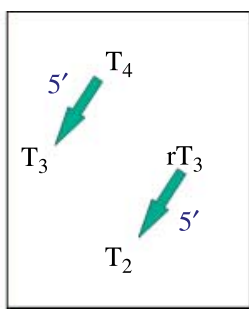

D2

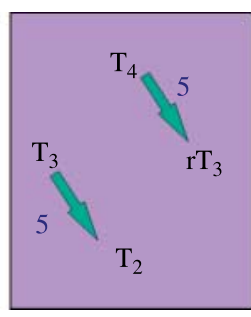

D3
Figure 3 Deiodination reactions catalyzed by the iodothyronine deiodinase isoenzymes D1, D2 and D3. of prolonged critical illness ( 7 days following infliction of full thickness burn injury) TRH in the PVN was decreased accompanied by an increase in hypothalamic D2 expression. Although hypothalamic $\mathrm{T}_{3}$ levels were unchanged, this does not preclude localised changes in the environment of the PVN and arcuate nucleus (Mebis et al. 2009b).

Locally produced cytokines may exert an important negative feedback regulation on TSH release by the thyrotroph in the pituitary (Prummel et al. 2004). Proinflammatory cytokines produced peripherally by patients with sepsis, trauma and autoimmune disease may thus also act directly on the pituitary thyrotroph to impair TSH release. Interleukin (IL)-6 appears particularly potent at suppressing TSH in plasma, but other cytokines, including TNF- $\alpha$ and interferon- $\gamma$, may have a similar effect (Boelen et al. 1993, 1995, 1996, 2004a,c).

Stress and a number of drugs such as glucocorticoids and dopaminergic drugs also suppress TSH (Fliers et al. 1997, Bartalena et al. 1998, Van den Berghe et al. 1998).

\section{Thyroid hormone metabolism in health and illness}

Whilst the thyroid gland provides the only source of $T_{4}$ for peripheral tissues, a fine regulation of the thyroid hormone environment in extra-thyroidal tissues is made possible by differential tissue expression of the iodothyronine deiodinases. These enzymes are capable of metabolising $T_{4}$ to the biologically active $T_{3}$, or bio-inactive reverse $T_{3}\left(r T_{3}\right)$ and $\mathrm{T}_{2}$. It is now clear that the expression of these deiodinases is modified by illness and such modifications can be highly organ specific resulting in tissue-specific modifications to thyroid status in illness.

\section{Health}

The thyroid produces $\mathrm{T}_{4}$ in significantly larger quantities than the biologically active $T_{3}$. Although released from the thyroid in a ratio of $\sim 17: 1\left(\mathrm{~T}_{4}: \mathrm{T}_{3}\right.$; Pilo et al. 1990), the circulating levels of each hormone are also determined by extra-thyroidal conversion of $\mathrm{T}_{4}$ to $\mathrm{T}_{3}$, which in healthy humans accounts for more than $80 \%$ of $\mathrm{T}_{3}$ production. Activation and inactivation of thyroid hormone are carried out by a group of three iodothyronine deiodinases, each of which is a selenoprotein encoded by a separate gene. The deiodinases D1, D2 and D3 have distinct tissue distributions, substrate affinities and physiological roles (Fig. 3; Bianco \& Kim 2006, Gereben et al. 2008a,b). All deiodinases are integral membrane proteins, and although their cellular localisation varies, all their catalytic domains reside within the cell cytosol (Toyoda et al. 1995, Baqui et al. 2000, Friesema et al. 2006). D1 and D2 activate $\mathrm{T}_{4}$ by removing an iodine atom from its outer ring ( $5^{\prime}$ deiodination), forming $\mathrm{T}_{3}$. On the other hand, D3 inactivates both $\mathrm{T}_{3}$ and $\mathrm{T}_{4}$ by removing an iodine atom from the inner ring (5-deiodination) generating $\mathrm{T}_{2}$ and $\mathrm{rT}_{3}$ respectively, a reaction that can also be catalyzed by $\mathrm{D} 1$ 
(Fig. 3). The D1 and D3 isoenzymes are located in the plasma membrane, whilst D2 is retained in the endoplasmic reticulum. The $\mathrm{T}_{3}$ produced from $\mathrm{D} 2$ thus potentially has ready access to the nucleus due to its close proximity (Zeold et al. 2006a,b), whilst $\mathrm{T}_{3}$ produced by $\mathrm{D} 1$ is more readily exported into plasma. These differences in intracellular location may explain why D2 appears particularly adept at supplying $\mathrm{T}_{3}$ for local use in the nucleus of the cell particularly in tissues such as brain, pituitary and brown adipose tissue (Bianco et al. 2002, Galton et al. 2009), whilst tissues that express high levels of D1 such as liver and kidney export into plasma much of the $\mathrm{T}_{3}$ they produce (Chanoine et al. 1993, Bianco et al. 2002, Bianco \& Kim 2006).

Debate has continued for many years regarding the predominant source of plasma $\mathrm{T}_{3}$ in humans. Although initially D1 was thought to provide the majority of plasma $T_{3}$ in humans, as is the case in rodents, further investigations provided evidence to suggest that D2 may quantitatively be a more important source of plasma $\mathrm{T}_{3}$ than D1. For example, treatment with the D1 inhibitor PTU only leads to an $\sim 30 \%$ decrease in serum $\mathrm{T}_{3}$ in patients with primary hypothyroidism receiving fixed doses of exogenous $T_{4}$, suggesting an important potential role for D2 in generation of plasma $T_{3}$ (Geffner et al. 1975, Saberi et al. 1975, LoPresti et al. 1989).

Whilst initial studies suggested that in humans as much as two-thirds of plasma $T_{3}$ may be generated by $\mathrm{D} 2$ from skeletal muscle (Maia et al. 2005), it has become clear that D2 activity in skeletal muscle may have been markedly overestimated in these early studies. The assay for deiodinase activity involves assessing the release of iodine from iodinated iodothyronines. It seems that in muscle homogenates, iodide can be released from $\mathrm{T}_{4}$ without the generation of $\mathrm{T}_{3}$; thus providing an overestimate of D2 activity in this tissue (Larsen 2009). It now appears that D2 activity in human skeletal muscle is in fact very low (Heemstra et al. 2009). Thus, whilst D2 may still contribute to circulating $\mathrm{T}_{3}$ in humans, it appears that skeletal muscle is not an important tissue source.

Whilst under normal circumstances D1 and D2 appear to provide important systemic and local sources of $\mathrm{T}_{3}$ respectively, it seems that at least in rodents, deiodinase action is not critical for maintenance of plasma $T_{3}$ concentrations (Galton et al. 2009, St Germain et al. 2009). D1 and D2 knockout mice maintain normal plasma $T_{3}$ concentrations, and their general health and reproductive capacity appear to be unimpaired. However, D2 knockout animals do show deficits in TSH regulation and thermogenesis, and the $T_{3}$ content of brain is decreased in these animals despite brain $\mathrm{T}_{4}$ being increased. These changes in brain thyroid hormone content are associated with only minimal changes in expression of thyroid hormone-responsive genes, motor function and learning ability. These findings support the view that $5^{\prime}$ deiodinase action (D1 or D2) is not essential for general health or maintenance of plasma $T_{3}$.

Combined D1/D2 knockout mice have plasma $\mathrm{T}_{4}$ almost twice that found in wild-type animals and a plasma TSH of $2 \cdot 6$ times the level found in wild type or D1 knockout.
The levels of plasma $\mathrm{rT}_{3}$ showed the most dramatic differences between genetic strains with the D2 knockout having no effect on $\mathrm{rT}_{3}$, whilst D1 and combined D1/D2 knockout had an increase in serum $\mathrm{rT}_{3}$ of two- and sixfold respectively. The increase in $\mathrm{rT}_{3}$ seen in the D1/D2 knockout may be due to impaired catabolism of $\mathrm{rT}_{3}$ through diminished $5^{\prime}$-deiodination and/or enhanced $\mathrm{rT}_{3}$ production from $\mathrm{T}_{4}$ catalyzed by D3. It is clear that D3 has an important role in the production of $\mathrm{rT}_{3}$, since $\mathrm{rT}_{3}$ is undetectable in the triple $\mathrm{D} 1 / \mathrm{D} 2 / \mathrm{D} 3$ knockout mouse (Galton et al. 2009).

These largely unexpected observations in the D1/D2 knockout mice raise major questions regarding the role of the deiodinases in maintaining thyroid status and also the role that these deiodinases may play in the NTIS (see below). The most likely explanation for the maintenance of plasma $T_{3}$ in the D1/D2 knockout animals is that enhanced thyroidal production of $\mathrm{T}_{3}$ takes place, a process driven by the increase in TSH concentration that occurs in these animals. This explanation is also consistent with the observation that selenium-deficient rats that express very low levels of renal and hepatic D1 largely maintain plasma $T_{3}$ through an increased thyroidal production of the hormone (Beckett \& Arthur 2005).

\section{Illness}

Data concerning the potential role of the deiodinases in the pathogenesis of NTIS is conflicting. The generally accepted view was that extra-thyroidal conversion of $T_{4}$ to $T_{3}$ is diminished in illness due to a diminution in both hepatic/renal D1 activity and skeletal muscle D2 activity. In addition to these changes, there may be an increase in hepatic and skeletal muscle D3 activity, which leads to increased production of $\mathrm{rT}_{3}$ from $\mathrm{T}_{4}$ and increased catabolism of $\mathrm{T}_{3}$ to produce $\mathrm{T}_{2}$ (Chopra 1997, Peeters et al. 2005, De Groot 2006). It was argued that together these modifications to deiodinase expression could be the major contributors to the low $\mathrm{T}_{3}$ concentrations associated with the NTIS. The trigger for these changes in deiodinase expression has been attributed to an increase in serum glucocorticoids and pro-inflammatory cytokines that often occurs in NTIS (Boelen et al. 1995, 2005, Hosoi et al. 1999, Jakobs et al. 2002, Kwakkel et al. 2007, 2009).

The validity of these conclusions has, however, now been challenged, and some have argued that the modifications to deiodinase expression in the NTIS may be a consequence of the changes that occur in $T_{3}$ and $T_{4}$, rather than the cause of these hormonal changes (O'Mara et al. 1993, Debaveye et al. 2008). This hypothesis is supported by studies on both D3 knockout mice (Boelen et al. 2009) and D1/D2 knockout mice (St Germain et al. 2009) subjected to treatment with LPS. In these mice, the changes in $\mathrm{T}_{3}$ and $\mathrm{T}_{4}$ that occurred in response to LPS were essentially no different from the changes seen in wild-type animals.

Furthermore, in wild-type mice injected with LPS, the decrease in plasma total $T_{3}$ and total $T_{4}$ precedes the fall in hepatic D1 with D2 expression in muscle being increased by 
such treatment (Kwakkel et al. 2008). In humans, it seems that skeletal muscle D2 does not contribute to the low $\mathrm{T}_{3}$ syndrome in either prolonged or acute illness, and indeed in prolonged critical illness a two- to threefold increase in muscle D2 expression occurs (Mebis et al. 2007).

In mice, inflammation induced by turpentine increases D2 in skeletal muscle but in contrast infection with Streptococcus pneumoniae leads to a decrease in muscle D2 (Kwakkel et al. 2009). These seemingly paradoxical D2 responses may be related to the different inflammatory signalling cascades that occur in the two models of illness. The D2 increase following turpentine administration results from activation of the cAMP pathway, whilst in severe bacterial infection D2 is downregulated as a response to diminished food intake and IL-1 $\beta$ release (Kwakkel et al. 2009).

A decrease in $T_{3}$ may also be a consequence of increased catabolism of $\mathrm{T}_{3}$ by $\mathrm{D} 3$. In critically ill patients, $\mathrm{D} 3$ expression occurs in skeletal muscle and liver, tissues which usually do not express the deiodinase in the adult (Peeters et al. 2005). The expression of D3 was found to be positively correlated with $\mathrm{rT}_{3}$ in serum and negatively correlated with serum $\mathrm{T}_{3}$, which raises the question of whether D3 expression in liver and skeletal tissue may be important contributors to the low $\mathrm{T}_{3}$ in chronic NTIS in humans.

The above-mentioned observations thus question the role of the D1 and D2 deiodinases in the pathogenesis of the low plasma $T_{3}$ seen in NTIS at least in the acute situation (Boelen et al. 2008, 2009, Debaveye et al. 2008, St Germain et al. 2009). The results suggest that the rapid fall in $T_{3}$ seen in acute illness is more likely to be due to either impaired thyroidal production of $\mathrm{T}_{3}$ (due to central hypothyroidism) and/or the result of the acute phase response leading to a diminution in serum thyroid hormone-binding proteins (discussed later).

An important role of thyroidal potassium channels for the maintenance of adequate thyroid hormone production has very recently been described (Roepke et al. 2009). No data currently exist regarding the influence of illness on the activity of these potassium channels.

\section{Selenium status, deiodination and the NTIS}

As plasma selenium levels are often low in sick patients, especially those with severe illness and sepsis (Maehira et al. 2002), it has been suggested that the expression of the selenoenzymes D1, D2 and D3 may be limited by the low selenium supply in these patients, and that this represents a mechanism for the pathogenesis of the low $\mathrm{T}_{3}$ seem in the NTIS. There is little evidence to support this view, indeed the typical plasma thyroid hormone profile seen in selenium deficiency is that plasma $T_{3}$ is well maintained due to a switch to thyroidal production, whilst total $\mathrm{T}_{4}$ rises in plasma (Beckett \& Arthur 2005, Gartner 2009). It seems more likely that the low selenium status seen in acute and chronically ill patients is a result of diminished concentrations of selenoproteins in plasma as a consequence of the acute phase response (Sammalkorpi et al. 1988, Maehira et al. 2002, Renko et al. 2009).

\section{Effects of illness on plasma thyroid hormones and thyroid hormone-binding proteins}

Thyroid hormones are bound, reversibly, to thyroxinebinding globulin (TBG), transthyretin (previously known as thyroxine-binding pre-albumin) and albumin. Transthyretin is the major $\mathrm{T}_{4} / \mathrm{T}_{3}$-binding protein in the plasma of rodents, whilst in humans TBG transports most of thyroid hormone in blood. Transthyretin and TBG are acute phase proteins and their concentration can fall markedly in a wide range of illnesses.

Under normal circumstance $<0.05 \%$ of the hormone circulates unbound (free) in plasma. The 'free hormone hypothesis' assumes that it is only this small 'free' hormone fraction that is able to enter the cell and interact with the nuclear THRs to confer biological action. Thus, the concentration of total $\mathrm{T}_{3}$ and total $\mathrm{T}_{4}$ in plasma is heavily dependent on the concentration of these binding proteins, whilst the free hormone concentrations should be largely independent of binding protein concentrations.

In severe NTI, the concentration of the thyroid hormonebinding proteins often decreases as a consequence of the 'acute phase response'; this arises from impaired synthesis, rapid breakdown and movement out of the plasma space (Jirasakuldech et al. 2000). For example, following bypass surgery, TBG levels may fall as much as $60 \%$ in $12 \mathrm{~h}$ (Afandi et al. 2000). The acute fall in these plasma binding proteins may thus account for much of the changes in plasma total $T_{3}$ and total $T_{4}$ seen in acute illness. In some, but not all patients with chronic illness, a desialylated form of TBG is synthesised by the liver, and this protein appears to have an affinity for thyroid hormone of approximately one-tenth of that of normal TBG (also known as slow TBG because of altered electrophoretic mobility); this also gives rise to a fall in the circulating levels of total thyroid hormone as a consequence of the diminished thyroid hormone binding capacity (Reilly \& Wellby 1983, Costante et al. 1985). In rodents, inflammation and fasting leads to a marked decrease in transthyretin, the major plasma thyroid hormone-binding protein in this species (Dickson et al. 1982, Wade et al. 1988).

Early literature suggested that substances, similar to nonesterified fatty acids (NEFA), may accumulate in plasma in the NTIS and inhibit the binding of $\mathrm{T}_{4}$ and $\mathrm{T}_{3}$ to their binding proteins, again lowering the thyroid hormone binding capacity of plasma. Much doubt has been cast on the role of NEFA as endogenously produced binding inhibitors for thyroid hormones (Mendel et al. 1991), since the concentration of NEFA in plasma rarely reaches that required to inhibit thyroid hormone binding in vitro. However, the serum binding capacity for thyroid hormone is significantly 
decreased in sick patients, and it is likely that many substances that compete with thyroid hormone binding to plasma proteins accumulate in the plasma of patients with hepatic and renal failure. Drugs such as furosemide, fenclofenac, carbamazepine and salicylate compete with the binding of thyroid hormone to plasma proteins at therapeutic concentrations; this also leads to a decrease in total $\mathrm{T}_{3}$ and total $\mathrm{T}_{4}$.

\section{Free thyroid hormone measurements in NTIS}

Equilibrium dialysis or ultrafiltration methods are widely regarded as reference methods for the measurement of free thyroid hormones in serum, although neither is completely satisfactory unless the measurement system has been well characterised (Fritz et al. 2007a,b). When using these dialysis methods, it is essential to minimise disruption of the original equilibrium by keeping both sample dilution and the ratio of the volumes of dialysing buffer and sample compartments as low as practically possible. If these conditions are met, samples from patients with NTI often show normal or raised $\mathrm{FT}_{4}$ in their serum and $\mathrm{FT}_{4}$ is rarely low (Fig. 1). In contrast, the use of significant sample dilution prior to equilibrium dialysis results in a fall in $\mathrm{FT}_{4}$ measured using these 'reference' methods (Beckett et al. 1991, Christofides et al. 1999a,b, Beckett 2006).

Many routine assays for the measurement of free thyroid hormone in serum are prone to artefacts that tend to underestimate the 'true' free hormone concentration that is in the serum of patients (and animals) with NTIS. Samples with the lowest serum binding capacity for thyroid hormones (NTIS samples) are particularly prone to this effect (Christofides et al. 1999a,b). Unfortunately, most published work regarding the effects of NTIS on free thyroid hormones have used inappropriate methodology, and these methodological artefacts have resulted in a mass of literature that gives a misleading picture of the effects of illness on free thyroid hormone concentrations in blood. Indeed, $\mathrm{FT}_{4}$ may appear to be low, normal or raised even in the same sample depending on the assay method (Beckett et al. 1991, Christofides et al. 1999a,b, Beckett 2006). In preterm infants, serum $\mathrm{FT}_{4}$ measured by equilibrium dialysis shows a much lower frequency of subnormal results than when the same samples are measured by routine diagnostic methods (Deming et al. 2007).

The reliable measurement of $\mathrm{FT}_{3}$ in serum has been even more problematic than for $\mathrm{FT}_{4}$ yet the measurement of the 'true' $\mathrm{FT}_{3}$ concentration in illness is fundamental to the perception of the 'thyroid status' of patients with NTI. The literature is quite clear that serum total $\mathrm{T}_{3}$ falls in illness, and the degree of this fall is often proportional to the severity of illness. Most routine methods for $\mathrm{FT}_{3}$ show that these concentrations tend to parallel the changes in serum total $\mathrm{T}_{3}$. However, results from two studies that have utilised a 'reference' ultrafiltration method for $\mathrm{FT}_{3}$ analysis have concluded that illness results in only a modest fall in serum $\mathrm{FT}_{3}$ (mean $\mathrm{FT}_{3}$ concentrations in NTIS group being only
10\% lower than the healthy control group; Faber et al. 1987, Faber \& Siersbaek-Nielsen 1996). Using a commercial FT 3 method that shows good agreement with the ultrafiltration reference method, we have found that the percentage of patients in an intensive care unit who had a $\mathrm{FT}_{3}$ below the reference range was in the order of $27 \%$, whilst $70-80 \%$ of patients had low total $T_{3}$. In the same study, using a reliable assay for $\mathrm{FT}_{4}$, we also found that whilst around $50 \%$ of patients had subnormal total $\mathrm{T}_{4}$ only around $2 \%$ had low $\mathrm{FT}_{4}$ (Fig. 4; Ray et al. 2002).

These observations support the view that the marked changes that occur in total thyroid hormone concentration during acute NTIS are largely due to changes in the serum binding capacity for thyroid hormones as a result of the acute phase response. Whilst free hormones do change in illness, it would appear that such changes are of a more modest nature than that of total thyroid hormone. It should be remembered that most published studies of the NTIS in small animals have measured only total thyroid hormone concentrations. Since the effect of the acute phase response on serum total thyroid hormone-binding proteins may be marked, it may mask more subtle changes that could be occurring in free hormone concentrations in the various animal models. Indeed, the importance of the acute phase response at influencing total $\mathrm{T}_{3}$ and total $\mathrm{T}_{4}$ may explain why these hormones fall in a similar fashion in wild-type and D1, D2 and D3 knockout mice after exposure to LPS.

It should be noted that in diseases that give rise to hepatic inflammation, plasma TBG concentrations (and thus the thyroid hormone binding capacity) may transiently increase as a consequence of increased release from the liver; this produces an increase in $\mathrm{TT}_{4}$ during the acute phase of such inflammatory conditions (Gardner et al. 1982).
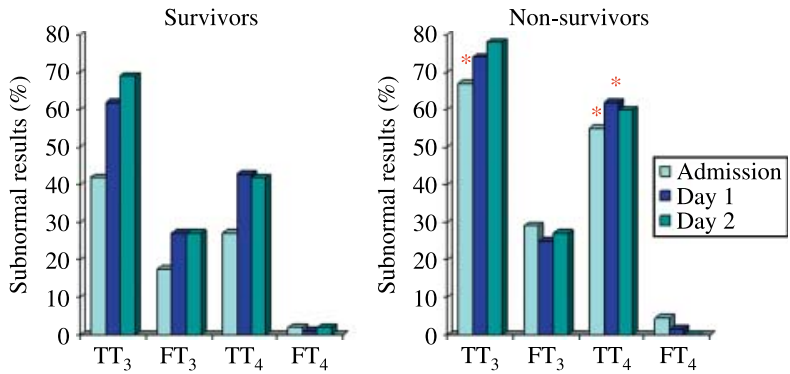

Figure 4 The percentage of patients admitted to an intensive care unit who had serum thyroid hormone and TSH concentrations below the lower reference limit. Data for the first 3 days of admission are shown in both survivors and non-survivors, and significant differences between these two groups are shown by $(*)$. Free $T_{4}$ and Free $T_{3}$ were measured by Amerlite MAB methodology (Ortho Clinical Diagnostics, Amersham), which show good correlation with equilibrium dialysis and ultrafiltration respectively (see text for details). Data taken from Table 4, Ray D C, Macduff A, Drummond G B, Wilkinson E, Adams B \& Beckett GJ 2002 Endocrine measurements in survivors and non-survivors from critical illness. Intensive Care Medicine 28 1301-1308 with kind permission from Springer Science \& Business Media. 


\section{Thyroid hormone uptake by tissue in NTIS; the role of thyroid hormone transporters}

Although changes in the circulating concentrations of thyroid hormones are commonly discussed in reference to NTIS, tissue thyroid status is governed by intracellular $\mathrm{T}_{3}$, particularly that which interacts with the THRs in the nucleus. Intracellular $T_{3}$ and $T_{4}$ is dependent not only on the local variation in the activity of D1, D2 and D3, but also on the ability of the cell to transport thyroid hormone. Clearly, if the cellular uptake of thyroid hormone is impaired, then intracellular deiodination of $\mathrm{T}_{4}$ cannot take place, giving rise to diminished peripheral production of $\mathrm{T}_{3}$ and also potentially local tissue hypothyroidism.

The cellular uptake of thyroid hormones is not simply the result of passive diffusion across the lipid bilayer, but involves ATP-dependent transport processes. Thyroid hormone transporters are required for both entry and exit of thyroid hormone from the cell, and these transporters have different tissue distributions and ligand affinities. Thyroid hormone transport proteins include Na-taurocholate cotransporting polypeptide, fatty acid translocase, multidrug resistance-associated proteins, amino acid transporters, and members of the organic anion transporter polypeptide (OATP) and monocarboxylase transporter (MCT) families (discussed below).

The majority of the thyroid hormone transporters demonstrate a low specificity and an apparently low affinity for thyroid hormone. As yet, only three key transporters with both a high affinity and a high specificity for thyroid hormone have been identified. OATP1C1 is localised in the brain capillaries and transports $\mathrm{T}_{4}$ and $\mathrm{rT}_{3}$. MCT8, localised in the brain, hypothalamus, pituitary gland, liver, heart and placenta, skeletal muscle, kidney and MCT10, found in the intestines, liver, kidney, skeletal muscle and placenta (Visser 2007, Visser et al. 2008, Dayan \& Panicker 2009) both transport $\mathrm{T}_{4}$ and $\mathrm{T}_{3}$.

The physiological importance of thyroid hormone transporters is exemplified by mutations in the MCT8 gene. Mutations in this transporter have been associated with a form of X-linked mental retardation in about 20 different families. In addition to the psychomotor effects, these patients present with abnormal serum thyroid hormones, highly elevated $\mathrm{T}_{3}$, decreased $\mathrm{T}_{4}$ and normal TSH. In the MCT8 knockout mouse, these same abnormalities in serum thyroid hormones are seen but without evidence of neurological impairment (Dumitrescu et al. 2006, Trajkovic et al. 2007). Importantly, the impact of MCT8 deletion was tissue specific. Neither the entry of $T_{3}$ nor the entry of $T_{4}$ into the liver was found to be affected, perhaps not surprising given the multiple thyroid hormone transporters that are expressed here. As hepatic thyroid hormone uptake is not impeded, the high serum $T_{3}$ levels are translated into high intracellular $\mathrm{T}_{3}$ levels, as demonstrated by an increased expression of hepatic D1. Indeed, both groups believe that these livers may be in a state of hyperthyroidism (as SHBG and other markers of hyperthyroidism are elevated). Although not crucial to thyroid hormone transport in the liver, it appears that MCT8 has a pivotal role for transportation of $\mathrm{T}_{3}$ into the brain since in the knockout model, $\mathrm{T}_{3}$ uptake into the brain was almost absent. $\mathrm{T}_{4}$ was not affected, which has been attributed to the presence of other $\mathrm{TH}$ transporters such as OATP1C1 at the blood-brain barrier that exhibit a restricted specificity towards $T_{4}$ (Trajkovic et al. 2007). It has been suggested that impaired $T_{3}$ uptake in the brain may be the primary event in the generation of the high $\mathrm{T}_{3}$ levels, reduced uptake preventing significant $\mathrm{T}_{3}$ inactivation by neuronally localised D3 (Trajkovic et al. 2007).

In NTIS, transport of thyroid hormone into tissues is diminished but this does not appear to be due to a downregulation of the expression of thyroid hormone transporters; indeed, the expression of these transporters appears to be increased in both chronic and acute illness. Mebis et al. (2009a) found that an increase in MCT8 but not MCT10 gene expression occurs in the liver and skeletal muscle of patients in an intensive care unit with prolonged critical illness. The expression of the MCT8 gene demonstrated a strong inverse correlation with circulating $\mathrm{TT}_{3}$ and $\mathrm{TT}_{4}$. Using a rabbit model of prolonged critical illness (full thickness burn injury), this group observed an increase in hepatic MCT8, an induction of MCT10 in skeletal muscle and an increase in MCT10 and OATP1C1 in the hypothalamus (Mebis et al. 2007, 2009a). In this rabbit model, treatment with $\mathrm{T}_{3}$ and $\mathrm{T}_{4}$ produced a subsequent downregulation of MCT8 expression in liver and MCT10 in muscle; again transporter expression correlated inversely with circulating thyroid hormone concentrations. These observations suggest that changes in the expression of thyroid transporters are a consequence rather than a cause of the changes in the concentration of plasma thyroid hormone found in NTI. In contrast to the observations of Mebis et al., Rodriguez-Perez et al. (2008) observed that MCT8 expression was unchanged in skeletal muscle of patients with septic shock but declined in subcutaneous adipose tissue; liver was not investigated.

Current evidence thus suggests that downregulation of thyroid hormone transporters does not occur in the NTIS, and other mechanisms must be responsible for the impaired uptake of thyroid hormone that is manifest in illness. Such mechanisms may include depletion of hepatic ATP or the presence in plasma of substances that impair hepatic uptake of thyroid hormone. NEFA and numerous substances that accumulate in the plasma of patients with renal or liver dysfunction inhibit cellular transport of $\mathrm{T}_{4}$ into cultured hepatocytes (Hennemann et al. 2001).

\section{Expression of THRs in illness}

Thyroid hormone action is largely dependent upon binding to THRs, which are ligand-regulated transcription factors that bind to thyroid hormone response elements (TREs) in target genes. THRs reside in both the nucleus and cytoplasm 
of the cell, and there is shuttling of these receptors between the two compartments (Davis et al. 2008). THRs in the nucleus form heterodimers with retinoid $\mathrm{X}$ receptors (RXR) which are another member of the nuclear receptor superfamily. These THR/RXR dimers bind to the target DNA sequences of the TREs to form a complex, which leads to the recruitment of transcriptional coactivators and corepressors.

The THRs are encoded by two genes, THRA and THRB, which give rise to several major THR isoforms, THR $\alpha 1$ (THR $\alpha 2$ does not bind TH), THR $\beta 1$ and THR $\beta 2$, which bind $T_{3}$ with similar affinity and have similar transcriptional activity (for a review of thyroid hormone action see Oetting \& Yen (2007)). This transcriptional activity is modulated by corepressors and coactivators. In the absence of $\mathrm{T}_{3}$, THRs bind to TREs and repress basal transcription of positively regulated target genes through association with a variety of corepressors, which include nuclear receptor corepressor (NCOR1), and silencing mediator of retinoic acid receptor and THR. Coactivators include steroid receptor coactivator (SRC-1) complex, which is one of at least two major complexes involved in ligand-dependent transcriptional activation of the nuclear hormone receptors.

A number of studies have examined the changes in the expression of THRs in models of the NTIS, with somewhat conflicting findings. Early work in patients with liver failure or chronic renal failure showed increased THR $\alpha$ and THR $\beta$ mRNA expression in peripheral mononuclear cells and liver tissue taken from biopsy (Williams et al. 1989). More recently, data from models of acute illness have been published, which have included mice treated with LPS or cytokines (Beigneux et al. 2003, Boelen et al. 2004b, Feingold et al. 2004) and patients with septic shock (Rodriguez-Perez et al. 2008) and in each model, THR expression is diminished. In the mouse LPS-treated model, a rapid and marked decrease in THR $\alpha$ and THR $\beta$ occurs accompanied by a decrease in the expression of the RXR isoforms. SRC- 1 and other coactivators in the heart (Feingold et al. 2004). In agreement with these studies, but in contrast to the findings of Williams et al. 1989, Boelen et al. (2004b) reported a rapid decrease in liver Thr $\beta 1$ mRNA after LPS administration in an animal model. A lowering of THR $\beta 1$ mRNA in response to inflammatory cytokines also occurs in vitro using a hepatoma cell line (Yu \& Koenig 2000). In the rabbit model of prolonged ( 7 days) burn injury, THRs were unchanged (Mebis et al. 2009b). Thus, in general, it appears that in chronic illness, THR expression is increased, whilst in acute illness THR expression is downregulated.

In humans with septic shock, a diminished expression of THR $\beta 1$ was seen after 5 days but with no associated change in THR $\alpha 1$, whereas decreases were seen in both receptors in subcutaneous adipose tissue. No differences were found in NCOR 1 or SRC-1 in either tissue. The RXR showed both isoform and tissue-specific changes in expression in these patients. For example, in smooth muscle, $R X R \alpha$ mRNA increased, RXR $\beta$ mRNA was unchanged and $R X R \gamma$ decreased.
THR $\beta 1$ is regarded as the main regulator of D1 expression in the liver (Amma et al. 2001), with increased $T_{3}$ levels acting via THR $\beta 1$, to induce hepatic D1. In the absence of TR $\beta 1$, liver D1 mRNA expression is decreased, although THR $\alpha 1$ can partly take over the role of TR $\beta 1$ to induce $\mathrm{D} 1$ by $\mathrm{T}_{3}$ (Amma et al. 2001). As such, changes in the expression of THR $\beta$ would be expected to have profound effects on the expression of D1 in the liver and perhaps also the circulating concentrations of $T_{3}$. This hypothesis has recently been challenged in light of results obtained using an LPS model of acute illness in knockout THR $\beta-/-$ mice (Kwakkel et al. 2008). In a 24-h period after LPS treatment, similar relative decreases were found in $\mathrm{T}_{3}, \mathrm{~T}_{4}$ and liver $\mathrm{D} 1 \mathrm{in}$ both wild-type and THR $\beta-/-$ knockout mice. These observations have led to the conclusion that the decrease in liver D1 mRNA and activity observed in illness is not mediated via THR $\beta 1$.

The involvement of changes in coactivator and corepressor expression in the NTIS should also be considered. This is exemplified by the effects of IL-1 and IL-6, which impairs the ability of $\mathrm{T}_{3}$ to induce D1 expression in primary cultures of rat hepatocytes. This effect could be partially overcome by cotransfection of the coactivator SRC-1 (Yu \& Koenig 2000). Similarly in a mouse model, the decrease in hepatic D1 and plasma $T_{3}$ caused by LPS could be prevented by forced expression of SRC-1 (Yu \& Koenig 2006). These observations are consistent with the view that cytokine-induced competition for limiting amounts of coactivators may be one mechanism behind the diminished hepatic D1 expression seen in the NTIS.

\section{Should thyroid hormone replacement be advocated in NTIS?}

Controversy surrounds the need for thyroid hormone replacement therapy in the NTIS. There have been very few clinical studies designed to address whether such replacement is advantageous, and if so which preparation $\left(\mathrm{T}_{3}\right.$ or $\mathrm{T}_{4}$ ) should be used. If as is sometimes argued, the changes represent a physiological adaptation, attempts to restore thyroid hormone levels could even have adverse effects on patient outcome.

In a study of intensive care patients randomly assigned to $\mathrm{T}_{4}$ or a placebo for 2 weeks, no improvement in survival was seen (Brent \& Hershman 1986). The use of $T_{3}$ as the principal treatment on burns patients has similarly shown no improvement to outcome (Becker et al. 1982). A more novel approach to replacement in critically ill patients has been suggested by Van den Berghe et al. $(1999,2002)$. They used a continuous infusion of TRH together with a GH secretagogue and successfully restored both thyroid hormone and TSH concentration, and found improvements in catabolic parameters.

Given that thyroid hormones have significant effects on cardiac function, the consequence of thyroid hormone replacement on cardiac patients has been studied in a number 


\begin{tabular}{|l|l|l|}
\hline Hypothalamus & $\begin{array}{l}* \text { Malnutrition } \rightarrow \downarrow \text { Leptin } \rightarrow \downarrow \mathrm{TRH} \\
* \text { Sepsis/Inflammation } \rightarrow \uparrow \mathrm{D} 2 \text { (tanycyte) } \rightarrow \uparrow \mathrm{T}_{3} \rightarrow \downarrow \mathrm{TRH}\end{array}$ \\
\cline { 2 - 3 } & Pituitary & $*$ Cytokines $\rightarrow \downarrow \mathrm{TSH}$ \\
\cline { 2 - 3 } & $\begin{array}{l}* \text { Acute phase response } \rightarrow \downarrow \mathrm{TBG} \rightarrow \downarrow \mathrm{TT}_{4} \downarrow \mathrm{TT}_{3} \\
* \uparrow \text { Competitors for TH binding proteins } \rightarrow \downarrow \mathrm{TT}_{4} \downarrow \mathrm{TT}_{3} \\
* \text { Free } \mathrm{T}_{3} \text { and free } \mathrm{T}_{4} \text { may also fall due to a central } \\
\text { hypothyroidism }\end{array}$ \\
\hline Tissue uptake & $\begin{array}{l}* \downarrow \mathrm{T}_{4} / \mathrm{T}_{3} \text { uptake } \\
* \uparrow \text { or unchanged thyroid hormone transporter } \\
\text { expression }\end{array}$ \\
\hline
\end{tabular}

Figure 5 Summary of the mechanisms that give rise to the serum thyroid hormone changes in the non-thyroidal illness syndrome.

of settings including surgery, heart failure and transplant. These have been reviewed at length (Farwell 2008). It is suggested that $T_{3}$ may be beneficial for stabilisation or improvement of cardiac function in donors before cardiac transplantation. Indeed, several consensus conferences in the US and Canada have recommended that $\mathrm{T}_{3}$ be included in a panel of hormones that are aimed at cardiac resuscitation, when the ejection fraction is $<45 \%$. Short-term studies involving $\mathrm{T}_{4}$ and $\mathrm{T}_{3}$ treatment in heart failure patients also show promise, with one of the observed benefits being increased cardiac output. No studies have so far looked at its long-term use in these patients.

Despite some promising work in both human and animal models, there is as yet no persuasive evidence for the use of thyroid hormone replacement in any patient with NTIS with the possible exception of patients with cardiac failure.

\section{Changes in thyroid function tests during recovery from illness}

When a patient recovers from illness, abnormalities in serum TSH and thyroid hormone concentrations eventually resolve. In some patients, however, TSH concentrations may rise transiently above the reference range in this recovery phase. In hospitalised patients, an elevated TSH is as likely to be due to recovery from NTIS as primary hypothyroidism (Spencer 1988, Stockigt 1996), and it is essential that clinicians understand this in order to avoid misdiagnosis that could lead to inappropriate lifelong $T_{4}$ replacement therapy. Prospective studies on critically ill patients with burns, sepsis and acute renal failure showed that the rise in TSH during recovery consistently preceded the rise in $T_{3}$ and $T_{4}$ suggesting that this TSH rise is essential in some patients to return thyroid hormone homoeostasis to normal during recovery (Hamblin et al. 1986).

\section{Conclusions}

The mechanisms behind the hormonal changes seen in the NTIS are now becoming clearer and are summarised in Fig. 5. Induction of a central hypothyroidism appears to be common in many models of illness. Inadequate calorie intake resulting in decreased leptin can lead to central hypothyroidism due to diminished hypothalamic TRH in the neurons of the PVN. In addition, sepsis or trauma increases the expression of D2 in hypothalamic tanocytes, which may increase the $\mathrm{T}_{3}$ supply to the TRH neurons in the PVN, thus suppressing TRH production. Increased cytokines in sepsis and trauma may also directly inhibit TSH release from the pituitary thyrotroph.

The total concentrations of plasma $T_{3}$ and $T_{4}$ fall acutely in illness and precede any decline in hepatic D1, whilst D2 in muscle is increased. It would seem, therefore, that much of the acute fall in circulating thyroid hormones in the NTIS can be attributed to an acute phase response giving rise to loss of plasma TBG or transthyretin and also the accumulation of substances that lower the thyroid hormone binding capacity of plasma. When measured by reliable methods, the fall in $\mathrm{FT}_{4}$ and $\mathrm{FT}_{3}$ may be modest in comparison to the fall seen in total thyroid hormone; unreliable methods for free hormone measurement considerably underestimate the 'true' free hormone concentration in the serum from sick patients.

Whilst in vitro cell studies suggest that thyroid hormone uptake by cells may be impaired in the NTIS, this is not the result of a downregulation of thyroid hormone transporters. Indeed, these transporters tend to be up-regulated or remain unchanged in many models of the NTIS. Thus, if diminished hormone uptake does occur in vivo, it is likely to be the result of diminished intracellular ATP or possible accumulation of substances in plasma that compete with thyroid hormones for the thyroid hormone transporters. Evidence from animal 
knockout models indicate that changes in D1 and D2 may have only a modest contribution to the low plasma $T_{3}$ in NTIS, at least in acute illness.

In humans, chronic illness appears to lead to an upregulation of THR expression, at least in liver and renal failure. In contrast, human and animal models of sepsis and trauma indicate that expression of THRs and their coactivators are diminished in acute illness.

Despite some promising work in both human and animal models, there is as yet no persuasive evidence for the use of thyroid hormone replacement in any patient with NTIS, with the possible exception of patients with cardiac failure.

\section{Declaration of interest}

The authors declare that there is no conflict of interest that could be perceived as prejudicing the impartiality of the research reported.

\section{Funding}

This research did not receive any specific grant from any funding agency in the public, commercial or not-for-profit sector.

\section{References}

Adriaanse R, Romijn JA, Brabant G, Endert E \& Wiersinga WM 1993 Pulsatile thyrotropin secretion in nonthyroidal illness. Journal of Clinical Endocrinology and Metabolism 77 1313-1317.

Afandi B, Schussler GC, Arafeh AH, Boutros A, Yap MG \& Finkelstein A 2000 Selective consumption of thyroxine-binding globulin during cardiac bypass surgery. Metabolism 49 270-274.

Amma LL, Campos-Barros A, Wang Z, Vennstrom B \& Forrest D 2001 Distinct tissue-specific roles for thyroid hormone receptors beta and alpha1 in regulation of type 1 deiodinase expression. Molecular Endocrinology 15 467-475.

Arem R \& Cusi K 1997 Thyroid function testing in psychiatric illness: usefulness and limitations. Trends in Endocrinology and Metabolism 8 282-287.

Baqui MM, Gereben B, Harney JW, Larsen PR \& Bianco AC 2000 Distinct subcellular localization of transiently expressed types 1 and 2 iodothyronine deiodinases as determined by immunofluorescence confocal microscopy. Endocrinology 141 4309-4312.

Bartalena L, Cossu E, Grasso L, Velluzzi F, Loviselli A, Cirillo R \& Martino E 1993 Relationship between nocturnal serum thyrotropin peak and metabolic control in diabetic patients. Journal of Clinical Endocrinology and Metabolism 76 983-987.

Bartalena L, Bogazzi F, Brogioni S, Grasso L \& Martino E 1998 Role of cytokines in the pathogenesis of the euthyroid sick syndrome. European Journal of Endocrinology 138 603-614.

Becker RA, Vaughan GM, Ziegler MG, Seraile LG, Goldfarb IW, Mansour EH, McManus WF, Pruitt BA Jr \& Mason AD Jr 1982 Hypermetabolic low triiodothyronine syndrome of burn injury. Critical Care Medicine $\mathbf{1 0}$ 870-875.

Beckett GJ 2006 Thyroid function and thyroid function tests in non-thyroidal illness. CPD Bulletin: Clinical Biochemistry 7 107-116.

Beckett GJ \& Arthur JR 2005 Selenium and endocrine systems. Journal of Endocrinology 184 455-465.

Beckett GJ, Wilkinson E, Rae PW, Gow S, Wu PS \& Toft AD 1991 The clinical utility of a non-isotopic two-step assay (DELFIA) and an analogue radioimmunoassay (SimulTRAC) for free thyroxine compared. Annals of Clinical Biochemistry 28 335-344.

Beigneux AP, Moser AH, Shigenaga JK, Grunfeld C \& Feingold KR 2003 Sick euthyroid syndrome is associated with decreased TR expression and DNA binding in mouse liver. American Journal of Physiology. Endocrinology and Metabolism 284 E228-E236.
Bianco AC \& Kim BW 2006 Deiodinases: implications of the local control of thyroid hormone action. Journal of Clinical Investigation 116 2571-2579.

Bianco AC, Salvatore D, Gereben B, Berry MJ \& Larsen PR 2002 Biochemistry, cellular and molecular biology, and physiological roles of the iodothyronine selenodeiodinases. Endocrine Reviews 23 38-89.

Boelen A, Platvoet-Ter Schiphorst MC \& Wiersinga WM 1993 Association between serum interleukin- 6 and serum 3,5,3'-triiodothyronine in nonthyroidal illness. Journal of Clinical Endocrinology and Metabolism 77 1695-1699.

Boelen A, Platvoet-Ter Schiphorst MC \& Wiersinga WM 1995 Soluble cytokine receptors and the low 3,5,3'-triiodothyronine syndrome in patients with nonthyroidal disease. Journal of Clinical Endocrinology and Metabolism 80 971-976.

Boelen A, Schiphorst MC \& Wiersinga WM 1996 Relationship between serum 3,5,3'-triiodothyronine and serum interleukin-8, interleukin-10 or interferon gamma in patients with nonthyroidal illness. Journal of Endocrinological Investigation 19 480-483.

Boelen A, Kwakkel J, Platvoet-ter Schiphorst M, Baur A, Kohrle J \& Wiersinga WM 2004a Contribution of interleukin-12 to the pathogenesis of non-thyroidal illness. Hormone and Metabolic Research 36 101-106.

Boelen A, Kwakkel J, Thijssen-Timmer DC, Alkemade A, Fliers E \& Wiersinga WM 2004b Simultaneous changes in central and peripheral components of the hypothalamus-pituitary-thyroid axis in lipopolysaccharide-induced acute illness in mice. Journal of Endocrinology 182 315-323.

Boelen A, Kwakkel J, Platvoet-ter Schiphorst M, Mentrup B, Baur A, Koehrle J \& Wiersinga WM 2004c Interleukin-18, a proinflammatory cytokine, contributes to the pathogenesis of non-thyroidal illness mainly via the central part of the hypothalamus-pituitary-thyroid axis. European Journal of Endocrinology 151 497-502.

Boelen A, Kwakkel J, Alkemade A, Renckens R, Kaptein E, Kuiper G, Wiersinga WM \& Visser TJ 2005 Induction of type 3 deiodinase activity in inflammatory cells of mice with chronic local inflammation. Endocrinology 146 5128-5134

Boelen A, Kwakkel J, Wiersinga WM \& Fliers E 2006 Chronic local inflammation in mice results in decreased TRH and type 3 deiodinase mRNA expression in the hypothalamic paraventricular nucleus independently of diminished food intake. Journal of Endocrinology 191 707-714.

Boelen A, Wiersinga WM \& Fliers E 2008 Fasting-induced changes in the hypothalamus-pituitary-thyroid axis. Thyroid 18 123-129.

Boelen A, Kwakkel J, Wieland CW, St Germain DL, Fliers E \& Hernandez A 2009 Impaired bacterial clearance in type 3 deiodinase-deficient mice infected with Streptococcus pneumoniae. Endocrinology 150 1984-1990.

Brent GA \& Hershman JM 1986 Thyroxine therapy in patients with severe nonthyroidal illnesses and low serum thyroxine concentration. Journal of Clinical Endocrinology and Metabolism 63 1-8.

Chanoine JP, Braverman LE, Farwell AP, Safran M, Alex S, Dubord S \& Leonard JL 1993 The thyroid gland is a major source of circulating $\mathrm{T}_{3}$ in the rat. Journal of Clinical Investigation 91 2709-2713.

Chiamolera MI \& Wondisford FE 2009 Minireview: thyrotropin-releasing hormone and the thyroid hormone feedback mechanism. Endocrinology 150 1091-1096.

Chopra IJ 1997 Clinical review 86: euthyroid sick syndrome: is it a misnomer? Journal of Clinical Endocrinology and Metabolism 82 329-334.

Christofides ND, Wilkinson E, Stoddart M, Ray DC \& Beckett GJ 1999a Serum thyroxine binding capacity-dependent bias in an automated free thyroxine assay. Journal of Immunoassay 20 201-221.

Christofides ND, Wilkinson E, Stoddart M, Ray DC \& Beckett GJ $1999 b$ Assessment of serum thyroxine binding capacity-dependent biases in free thyroxine assays. Clinical Chemistry 45 520-525.

Coppola A, Liu ZW, Andrews ZB, Paradis E, Roy MC, Friedman JM, Ricquier D, Richard D, Horvath TL, Gao XB et al. 2007 A central thermogenic-like mechanism in feeding regulation: an interplay between arcuate nucleus $\mathrm{T}_{3}$ and UCP2. Cell Metabolism 5 21-33.

Costante G, Sand G, Reding P \& Glinoer D 1985 Absence of circulating desialylated thyroxine-binding globulin in patients with hepatobiliary disease. Acta Endocrinologica 108 392-400. 
Davis PJ, Davis FB \& Lin HY 2008 Promotion by thyroid hormone of cytoplasm-to-nucleus shuttling of thyroid hormone receptors. Steroids $\mathbf{7 3}$ 1013-1017.

Dayan CM \& Panicker V 2009 Novel insights into thyroid hormones from the study of common genetic variation. Nature Reviews. Endocrinology $\mathbf{5}$ 211-218.

Debaveye Y, Ellger B, Mebis L, Darras VM \& Van den Berghe G 2008 Regulation of tissue iodothyronine deiodinase activity in a model of prolonged critical illness. Thyroid 18 551-560.

De Groot LJ 2006 Non-thyroidal illness syndrome is a manifestation of hypothalamic-pituitary dysfunction, and in view of current evidence, should be treated with appropriate replacement therapies. Critical Care Clinics 22 57-86 (vi).

Deming DD, Rabin CW, Hopper AO, Peverini RL, Vyhmeister NR \& Nelson JC 2007 Direct equilibrium dialysis compared with two non-dialysis free $\mathrm{T}_{4}$ methods in premature infants. Journal of Pediatrics 151 404-408.

Dickson PW, Howlett GJ \& Schreiber G 1982 Metabolism of prealbumin in rats and changes induced by acute inflammation. European Journal of Biochemistry 129 289-293.

Dumitrescu AM, Liao XH, Weiss RE, Millen K \& Refetoff S 2006 Tissue-specific thyroid hormone deprivation and excess in monocarboxylate transporter (mct) 8-deficient mice. Endocrinology 147 4036-4043.

Faber J \& Siersbaek-Nielsen K 1996 Serum free 3,5,3'-triiodothyronine $\left(\mathrm{T}_{3}\right)$ in non-thyroidal somatic illness, as measured by ultrafiltration and immunoextraction. Clinica Chimica Acta 256 115-123.

Faber J, Kirkegaard C, Rasmussen B, Westh H, Busch-Sorensen M \& Jensen IW 1987 Pituitary-thyroid axis in critical illness. Journal of Clinical Endocrinology and Metabolism 65 315-320.

Farwell AP 2008 Thyroid hormone therapy is not indicated in the majority of patients with the sick euthyroid syndrome. Endocrine Practice 14 1180-1187.

Feingold K, Kim MS, Shigenaga J, Moser A \& Grunfeld C 2004 Altered expression of nuclear hormone receptors and coactivators in mouse heart during the acute-phase response. American Journal of Physiology. Endocrinology and Metabolism 286 E201-E207.

Fekete C \& Lechan RM 2007 Negative feedback regulation of hypophysiotropic thyrotropin-releasing hormone $(\mathrm{TRH})$ synthesizing neurons: role of neuronal afferents and type 2 deiodinase. Frontiers in Neuroendocrinology 28 97-114.

Fekete C, Gereben B, Doleschall M, Harney JW, Dora JM, Bianco AC, Sarkar S, Liposits Z, Rand W, Emerson C et al. 2004 Lipopolysaccharide induces type 2 iodothyronine deiodinase in the mediobasal hypothalamus: implications for the nonthyroidal illness syndrome. Endocrinology 145 1649-1655.

Fekete C, Singru PS, Sarkar S, Rand WM \& Lechan RM 2005 Ascending brainstem pathways are not involved in lipopolysaccharide-induced suppression of thyrotropin-releasing hormone gene expression in the hypothalamic paraventricular nucleus. Endocrinology 146 1357-1363.

Fliers E, Guldenaar SE, Wiersinga WM \& Swaab DF 1997 Decreased hypothalamic thyrotropin-releasing hormone gene expression in patients with nonthyroidal illness. Journal of Clinical Endocrinology and Metabolism 82 4032-4036.

Fliers E, Alkemade A \& Wiersinga WM 2001 The hypothalamic-pituitarythyroid axis in critical illness. Best Practice and Research. Clinical Endocrinology and Metabolism 15 453-464.

Fliers E, Alkemade A, Wiersinga WM \& Swaab DF 2006 Hypothalamic thyroid hormone feedback in health and disease. Progress in Brain Research 153 189-207

Friesema EC, Kuiper GG, Jansen J, Visser TJ \& Kester MH 2006 Thyroid hormone transport by the human monocarboxylate transporter 8 and its rate-limiting role in intracellular metabolism. Molecular Endocrinology 20 2761-2772.

Fritz KS, Wilcox RB \& Nelson JC 2007a Quantifying spurious free $\mathrm{T}_{4}$ results attributable to thyroxine-binding proteins in serum dialysates and ultrafiltrates. Clinical Chemistry 53 985-988.

Fritz KS, Weiss RM, Nelson JC \& Wilcox RB $2007 b$ Unequal concentrations of free $\mathrm{T}_{3}$ and free $\mathrm{T}_{4}$ after ultrafiltration. Clinical Chemistry 53 1384-1385.
Galton VA, Schneider MJ, Clark AS \& St Germain DL 2009 Life without thyroxine to $3,5,3^{\prime}$-triiodothyronine conversion: studies in mice devoid of the 5'-deiodinases. Endocrinology 150 2957-2963.

Gardner DF, Carithers RL Jr \& Utiger RD 1982 Thyroid function tests in patients with acute and resolved hepatitis B virus infection. Annals of Internal Medicine 96 450-452.

Gartner R 2009 Selenium and thyroid hormone axis in critical ill states: an overview of conflicting view points. Journal of Trace Elements in Medicine and Biology 23 71-74.

Geffner DL, Azukizawa M \& Hershman JM 1975 Propylthiouracil blocks extrathyroidal conversion of thyroxine to triiodothyronine and augments thyrotropin secretion in man. Journal of Clinical Investigation 55 224-229.

Gereben B, Zeold A, Dentice M, Salvatore D \& Bianco AC 2008a Activation and inactivation of thyroid hormone by deiodinases: local action with general consequences. Cellular and Molecular Life Sciences 65 570-590.

Gereben B, Zavacki AM, Ribich S, Kim BW, Huang SA, Simonides WS, Zeold A \& Bianco AC $2008 b$ Cellular and molecular basis of deiodinaseregulated thyroid hormone signaling. Endocrine Reviews 29 898-938.

Hamblin PS, Dyer SA, Mohr VS, Le Grand BA, Lim CF, Tuxen DV, Topliss DJ \& Stockigt JR 1986 Relationship between thyrotropin and thyroxine changes during recovery from severe hypothyroxinemia of critical illness. Journal of Clinical Endocrinology and Metabolism 62 717-722.

Heemstra KA, Soeters MR, Fliers E, Serlie MJ, Burggraaf J, van Doorn MB, van der Klaauw AA, Romijn JA, Smit JW, Corssmit EP et al. 2009 Type 2 iodothyronine deiodinase in skeletal muscle: effects of hypothyroidism and fasting. Journal of Clinical Endocrinology and Metabolism 94 2144-2150.

Hein MD \& Jackson IM 1990 Review: thyroid function in psychiatric illness. General Hospital Psychiatry 12 232-244.

Hennemann G, Docter R, Friesema EC, de Jong M, Krenning EP \& Visser TJ 2001 Plasma membrane transport of thyroid hormones and its role in thyroid hormone metabolism and bioavailability. Endocrine Reviews 22 $451-476$.

van der Heyden JT, Docter R, van Toor H, Wilson JH, Hennemann G \& Krenning EP 1986 Effects of caloric deprivation on thyroid hormone tissue uptake and generation of low- $\mathrm{T}_{3}$ syndrome. American Journal of Physiology 251 E156-E163.

Hosoi Y, Murakami M, Mizuma H, Ogiwara T, Imamura M \& Mori M 1999 Expression and regulation of type II iodothyronine deiodinase in cultured human skeletal muscle cells. Journal of Clinical Endocrinology and Metabolism 84 3293-3300.

Jakobs TC, Mentrup B, Schmutzler C, Dreher I \& Kohrle J 2002 Proinflammatory cytokines inhibit the expression and function of human type I 5'-deiodinase in HepG2 hepatocarcinoma cells. European Journal of Endocrinology 146 559-566.

Jirasakuldech B, Schussler GC, Yap MG, Drew H, Josephson A \& Michl J 2000 A characteristic serpin cleavage product of thyroxine-binding globulin appears in sepsis sera. Journal of Clinical Endocrinology and Metabolism $\mathbf{8 5}$ 3996-3999.

Kwakkel J, Wiersinga WM \& Boelen A 2007 Interleukin-1beta modulates endogenous thyroid hormone receptor alpha gene transcription in liver cells. Journal of Endocrinology 194 257-265.

Kwakkel J, Chassande O, van Beeren HC, Wiersinga WM \& Boelen A 2008 Lacking thyroid hormone receptor beta gene does not influence alterations in peripheral thyroid hormone metabolism during acute illness. Journal of Endocrinology 197 151-158.

Kwakkel J, van Beeren H, Ackermans M, Platvoet-Ter Schiphorst M, Fliers E, Wiersinga W \& Boelen A 2009 Skeletal muscle deiodinase type 2 regulation during illness in mice. Journal of Endocrinology 203 263-270.

Larsen PR 2009 Type 2 iodothyronine deiodinase in human skeletal muscle: new insights into its physiological role and regulation. Journal of Clinical Endocrinology and Metabolism 94 1893-1895.

Lechan RM 2008 The dilemma of the nonthyroidal illness syndrome. Acta Biomedica 79 165-171.

Lechan RM \& Fekete C 2004 Feedback regulation of thyrotropin-releasing hormone (TRH): mechanisms for the non-thyroidal illness syndrome. Journal of Endocrinological Investigation 27 105-119.

Lechan RM \& Fekete C 2005 Role of thyroid hormone deiodination in the hypothalamus. Thyroid 15 883-897. 
LoPresti JS, Eigen A, Kaptein E, Anderson KP, Spencer CA \& Nicoloff JT 1989 Alterations in $3,3^{\prime} 5^{\prime}$-triiodothyronine metabolism in response to propylthiouracil, dexamethasone, and thyroxine administration in man. Journal of Clinical Investigation 84 1650-1656.

Maehira F, Luyo GA, Miyagi I, Oshiro M, Yamane N, Kuba M \& Nakazato Y 2002 Alterations of serum selenium concentrations in the acute phase of pathological conditions. Clinica Chimica Acta 316 137-146.

Maia AL, Kim BW, Huang SA, Harney JW \& Larsen PR 2005 Type 2 iodothyronine deiodinase is the major source of plasma $\mathrm{T}_{3}$ in euthyroid humans. Journal of Clinical Investigation 115 2524-2533.

Mebis L, Langouche L, Visser TJ \& Van den Berghe G 2007 The type II iodothyronine deiodinase is up-regulated in skeletal muscle during prolonged critical illness. Journal of Clinical Endocrinology and Metabolism 92 3330-3333.

Mebis L, Paletta D, Debaveye Y, Ellger B, Langouche L, D'Hoore A, Darras VM, Visser TJ \& Van den Berghe G 2009a Expression of thyroid hormone transporters during critical illness. European Journal of Endocrinology 161 243-250.

Mebis L, Debaveye Y, Ellger B, Derde S, Ververs EJ, Langouche L, Darras VM, Fliers E, Visser TJ \& Van den Berghe G 2009b Changes in the central component of the hypothalamus-pituitary-thyroid axis in a rabbit model of prolonged critical illness. Critical Care 13 R147.

Mendel CM, Laughton CW, McMahon FA \& Cavalieri RR 1991 Inability to detect an inhibitor of thyroxine-serum protein binding in sera from patients with nonthyroid illness. Metabolism 40 491-502.

Oetting A \& Yen PM 2007 New insights into thyroid hormone action. Best Practice \& Research. Clinical Endocrinology \& Metabolism 21 193-208.

O'Mara BA, Dittrich W, Lauterio TJ \& St Germain DL 1993 Pretranslational regulation of type I $5^{\prime}$-deiodinase by thyroid hormones and in fasted and diabetic rats. Endocrinology 133 1715-1723.

Peeters RP, Wouters PJ, van Toor H, Kaptein E, Visser TJ \& Van den Berghe G 2005 Serum 3,3',5'-triiodothyronine $\left(\mathrm{rT}_{3}\right)$ and 3,5, $3^{\prime}-$

triiodothyronine $/ \mathrm{rT}_{3}$ are prognostic markers in critically ill patients and are associated with postmortem tissue deiodinase activities. Journal of Clinical Endocrinology and Metabolism 90 4559-4565.

Pilo A, Iervasi G, Vitek F, Ferdeghini M, Cazzuola F \& Bianchi R 1990 Thyroidal and peripheral production of $3,5,3^{\prime}$-triiodothyronine in humans by multicompartmental analysis. American Journal of Physiology 258 E715-E726.

Premachandra BN, Kabir MA \& Williams IK 2006 Low $\mathrm{T}_{3}$ syndrome in psychiatric depression. Journal of Endocrinological Investigation 29 568-572.

Prummel MF, Brokken LJ \& Wiersinga WM 2004 Ultra short-loop feedback control of thyrotropin secretion. Thyroid 14 825-829.

Ray DC, Macduff A, Drummond GB, Wilkinson E, Adams B \& Beckett GJ 2002 Endocrine measurements in survivors and non-survivors from critical illness. Intensive Care Medicine 28 1301-1308.

Reilly CP \& Wellby ML 1983 Slow thyroxine binding globulin in the pathogenesis of increased dialysable fraction of thyroxine in nonthyroidal illnesses. Journal of Clinical Endocrinology and Metabolism 57 15-18.

Renko K, Hofmann PJ, Stoedter M, Hollenbach B, Behrends T, Kohrle J, Schweizer U \& Schomburg L 2009 Down-regulation of the hepatic selenoprotein biosynthesis machinery impairs selenium metabolism during the acute phase response in mice. FASEB Journal 23 1758-1765.

Rodriguez-Perez A, Palos-Paz F, Kaptein E, Visser TJ, Dominguez-Gerpe L, Alvarez-Escudero J \& Lado-Abeal J 2008 Identification of molecular mechanisms related to nonthyroidal illness syndrome in skeletal muscle and adipose tissue from patients with septic shock. Clinical Endocrinology 68 821-827.

Roepke TK, King EC, Reyna-Neyra A, Paroder M, Purtell K, Koba W, Fine E, Lerner DJ, Carrasco N \& Abbott GW 2009 Kcne2 deletion uncovers its crucial role in thyroid hormone biosynthesis. Nature Medicine 15 1186-1194.

Sabeen S, Chou C \& Holroyd S 2009 Abnormal thyroid stimulating hormone (TSH) in psychiatric long-term care patients. Archives of Gerontology and Geriatrics DOI: 10.1016/j.archger.2009.06.002.

Saberi M, Sterling FH \& Utiger RD 1975 Reduction in extrathyroidal triiodothyronine production by propylthiouracil in man. Journal of Clinical Investigation $\mathbf{5 5} 218-223$.

Sammalkorpi K, Valtonen V, Alfthan G, Aro A \& Huttunen J 1988 Serum selenium in acute infections. Infection 16 222-224.
Sergeyev V, Broberger C \& Hokfelt T 2001 Effect of LPS administration on the expression of POMC, NPY, galanin, CART and MCH mRNAs in the rat hypothalamus. Brain Research. Molecular Brain Research 90 93-100.

Spencer CA 1988 Clinical utility and cost-effectiveness of sensitive thyrotropin assays in ambulatory and hospitalized patients. Mayo Clinic Proceedings 63 1214-1222.

Spencer C, Eigen A, Shen D, Duda M, Qualls S, Weiss S \& Nicoloff J 1987 Specificity of sensitive assays of thyrotropin (TSH) used to screen for thyroid disease in hospitalized patients. Clinical Chemistry 33 1391-1396.

St Germain DL, Galton VA \& Hernandez A 2009 Minireview: defining the roles of the iodothyronine deiodinases: current concepts and challenges. Endocrinology 150 1097-1107.

Stockigt JR 1996 Guidelines for diagnosis and monitoring of thyroid disease: nonthyroidal illness. Clinical Chemistry 42 188-192.

Toyoda N, Berry MJ, Harney JW \& Larsen PR 1995 Topological analysis of the integral membrane protein, type 1 iodothyronine deiodinase (D1). Journal of Biological Chemistry 270 12310-12318.

Trajkovic M, Visser TJ, Mittag J, Horn S, Lukas J, Darras VM, Raivich G, Bauer K \& Heuer H 2007 Abnormal thyroid hormone metabolism in mice lacking the monocarboxylate transporter 8. Journal of Clinical Investigation 117 627-635.

Van den Berghe G, de Zegher F, Baxter RC, Veldhuis JD, Wouters P, Schetz M, Verwaest C, Van der Vorst E, Lauwers P, Bouillon R et al. 1998 Neuroendocrinology of prolonged critical illness: effects of exogenous thyrotropinreleasing hormone and its combination with growth hormone secretagogues. Journal of Clinical Endocrinology and Metabolism 83 309-319.

Van den Berghe G, Wouters P, Weekers F, Mohan S, Baxter RC, Veldhuis JD, Bowers CY \& Bouillon R 1999 Reactivation of pituitary hormone release and metabolic improvement by infusion of growth hormone-releasing peptide and thyrotropin-releasing hormone in patients with protracted critical illness. Journal of Clinical Endocrinology and Metabolism 84 1311-1323.

Van den Berghe G, Baxter RC, Weekers F, Wouters P, Bowers CY, Iranmanesh A, Veldhuis JD \& Bouillon R 2002 The combined administration of GH-releasing peptide-2 (GHRP-2), TRH and GnRH to men with prolonged critical illness evokes superior endocrine and metabolic effects compared to treatment with GHRP-2 alone. Clinical Endocrinology 56 655-669.

Visser TJ 2007 Thyroid hormone transporters. Hormone Research 68 (Suppl 5) 28-30.

Visser WE, Friesema EC, Jansen J \& Visser TJ 2008 Thyroid hormone transport in and out of cells. Trends in Endocrinology and Metabolism 19 50-56.

Wade S, Bleiberg-Daniel F \& Le Moullac B 1988 Rat transthyretin: effects of acute short-term food deprivation and refeeding on serum and cerebrospinal fluid concentration and on hepatic mRNA level. Journal of Nutrition 118 199-205.

Williams GR, Franklyn JA, Neuberger JM \& Sheppard MC 1989 Thyroid hormone receptor expression in the "sick euthyroid" syndrome. Lancet 2 $1477-1481$.

Yu J \& Koenig RJ 2000 Regulation of hepatocyte thyroxine $5^{\prime}$-deiodinase by $\mathrm{T}_{3}$ and nuclear receptor coactivators as a model of the sick euthyroid syndrome. Journal of Biological Chemistry 275 38296-38301.

Yu J \& Koenig RJ 2006 Induction of type 1 iodothyronine deiodinase to prevent the nonthyroidal illness syndrome in mice. Endocrinology 147 3580-3585.

Zeold A, Pormuller L, Dentice M, Harney JW, Curcio-Morelli C, Tente SM, Bianco AC \& Gereben B 2006a Metabolic instability of type 2 deiodinase is transferable to stable proteins independently of subcellular localization. Journal of Biological Chemistry 281 31538-31543.

Zeold A, Doleschall M, Haffner MC, Capelo LP, Menyhert J, Liposits Z, da Silva WS, Bianco AC, Kacskovics I, Fekete C et al. $2006 b$ Characterization of the nuclear factor-kappa $\mathrm{B}$ responsiveness of the human dio2 gene. Endocrinology 147 4419-4429.

\section{Received in final form 9 December 2009 Accepted 16 December 2009 Made available online as an Accepted Preprint 16 December 2009}

